\title{
Long-term survival of human faecal microorganisms on the Antarctic Peninsula
}

\author{
KEVIN A. HUGHES ${ }^{* 1}$ and SIMON J. NOBBS ${ }^{2}$ \\ ${ }^{1}$ British Antarctic Survey, NERC, High Cross, Madingley Road, Cambridge CB3 OET, UK \\ ${ }^{2}$ Department of Microbiology, Plymouth Hospitals NHS Trust, Derriford Hospital, Plymouth PL6 8DH, UK \\ *Corresponding author: k.hughes@bas.ac.uk
}

\begin{abstract}
Human faecal waste has been discarded at inland Antarctic sites for over 100 years, but little is known about the long-term survival of faecal microorganisms in the Antarctic terrestrial environment or the environmental impact. This study identified viable faecal microorganisms in 30-40 year old human faeces sampled from the waste dump at Fossil Bluff Field Station, Alexander Island, Antarctic Peninsula. Viable aerobic and anaerobic bacteria were predominantly spore-forming varieties (Bacillus and Clostridium spp.). Faecal coliform bacteria were not detected, indicating that they are less able to survive Antarctic environmental conditions than spore-forming bacteria. In recent years, regional warming around the Antarctic Peninsula has caused a decrease in permanent snow cover around nunataks and coastal regions. As a result, previously buried toilet pits, depots and food dumps are now melting out and Antarctic Treaty Parties face the legacy of waste dumped in the Antarctic terrestrial environment by earlier expeditions. Previous faecal waste disposal on land may now start to produce detectable environmental pollution as well as potential health and scientific problems.
\end{abstract}

Received 18 August 2003, accepted 26 April 2004

Key words: Antarctica, climate change, Environmental Protocol, faecal bacteria, faecal coliforms, freezing

\section{Introduction}

Since the first human exploration of coastal Antarctica at the end of the 19th century, disposal of faecal waste has generally been into the sea (Meyer et al. 1963, McFeters et al. 1993, Hughes 2003, Hughes \& Blenkharn 2003). With exploration inland, this method is not practical and most human waste has been left in situ, either buried in snow (Parker \& Martel 2002) or discharged to inland streams and lakes. Burial of human waste in ice pits is still common practice for inland research stations, situated on ice shelves or the polar plateau, and for both static and travelling field parties. Once buried and maintained at low temperatures, faecal waste in Antarctica undergoes relatively little degradation and could become a long-term pollution problem (Parker \& Martell 2002).

The British Antarctic Survey (BAS) Fossil Bluff Field Station is situated on Alexander Island beside George VI Ice Shelf (Fig. 1). The base was constructed in February 1961 and occupied in the winters of 1961, 1962 and 1969-75, after which time it has been operated as a summer-only station. During the 1960s, all rubbish generated at Fossil Bluff was deposited at a waste dump on the surface of the ice shelf. After 40 years, the dump has remained on the surface of the ice shelf and has not been buried by snow. It was removed completely in 2003. Until recently, toilet facilities at Fossil Bluff Field Station were primitive. Initially, faeces were excreted directly into empty flour tins and deposited on the dump. However, in the 1970s a chemical toilet was installed and the waste was then emptied into a nearby crevasse. Facilities to dispose of human faecal waste were significantly improved in 2000 when BAS installed a propane-fuelled incinerating toilet at the base.

This paper examined 30-40 year old human faecal waste found at Fossil Bluff dump to determine the long-term survival of faecal microorganisms in the Antarctic Peninsula.

\section{Materials and methods}

Meteorology

Air temperature at Fossil Bluff Field Station was measured every $6 \mathrm{~h}$ between January 1999 and December 2002 using a platinum resistance thermometer (accuracy $\pm 0.06^{\circ} \mathrm{C}$; RS Components, Corby, UK).

\section{Microbiology}

In February 2000, sealed flour tins containing faecal material, and snow and ice from around the Fossil Bluff waste dump were collected aseptically. Samples were placed in insulated containers and flown to Rothera Research Station $(\sim 1.5 \mathrm{~h})$ for immediate analysis. During the collection period the air temperature at Fossil Bluff was $+2^{\circ} \mathrm{C}$. Other flour tins, opened at the site, revealed that at that time the faecal material was unfrozen.

Faecal coliforms in melted snow (c. 11 ; melted overnight at $+4^{\circ} \mathrm{C}$ ) were enumerated in triplicate using membrane 


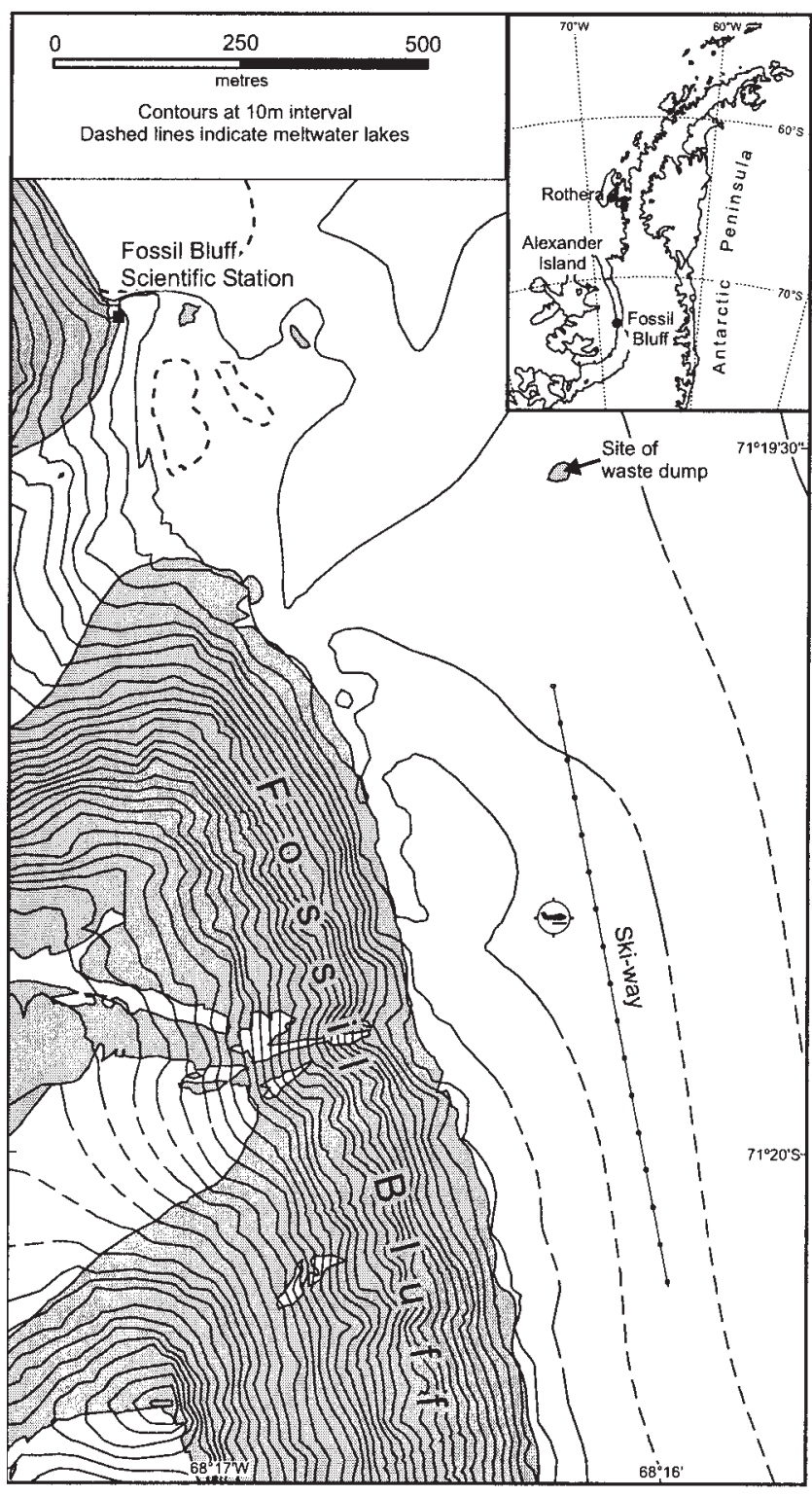

Fig, 1. Map of Fossil Bluff Field Station, showing the field station and dump site.

filtration $(0.2 \mu \mathrm{m}$, Sartorius, Goettinger, Germany) on membrane lauryl sulphate broth agar (MLSB; Oxoid, Basingstoke, UK) according to established procedures (Anon 1994). Immediately after opening the flour tins, faecal samples $(\sim 1 \mathrm{~g})$ were extracted from the centre of the unfrozen mass under aseptic conditions, suspended in $300 \mathrm{ml}$ of phosphate buffered saline (PBS; $\mathrm{pH}$ 7.2) and the supernatant filtered as before to enumerate faecal coliforms.

The remaining flour tins were stored at $-20^{\circ} \mathrm{C}$ and frozen samples were transported to Derriford Hospital, Plymouth, UK, for further microbiological analysis. Representative portions of the faecal material were treated as described in Table I, to culture a range of faecal bacteria (Public Health Laboratory Service 1998a, 1998b, Roberts et al. 1995).

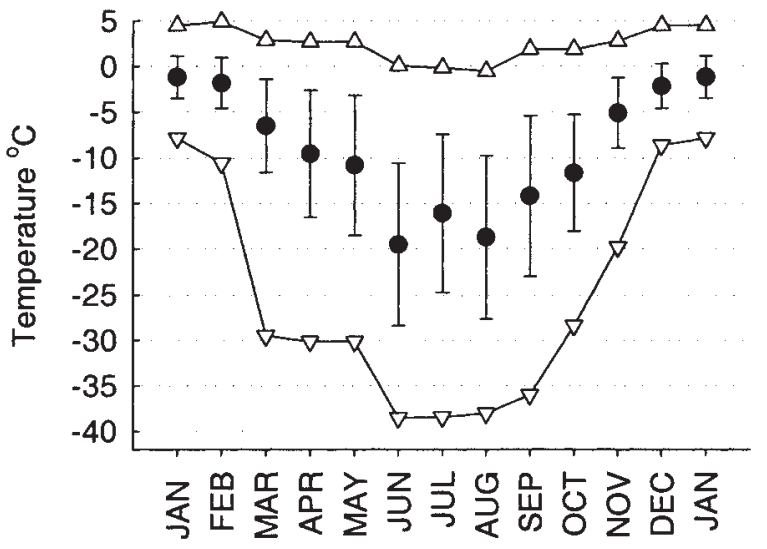

Fig. 2. Air temperature data recorded at Fossil Bluff Research Station. Plots represent mean $(\bullet ; \pm$ SD $)$, maximum $(\Delta)$ and minimum $(\nabla)$ monthly values over the period January 1999-December 2002.

Examination for intestinal parasites was performed by direct microscopic examination, and by the formol-ethyl acetate concentration method (Public Health Laboratory Service 1998c).

\section{Results}

Fossil Bluff experiences low precipitation and temperatures and has been characterised as having a continental rather than maritime climate (Harangozo et al. 1997). However, Fossil Bluff experiences mean summer temperatures (December-February) close to $0^{\circ} \mathrm{C}$ (Fig. 2) with regular daily positive maxima, and is likely to experience higher numbers of freeze/thaw events than at colder sites at higher latitudes.

Faecal material sampled from the dump was not in a frozen state upon collection indicating that this material may have undergone repeated cycles of freeze/thaw over the last 30-40 years. Preliminary microbiological examination at Rothera Research Station of faecal material and snow collected around Fossil Bluff dump did not reveal the presence of viable faecal coliforms. The results of more extensive microbiological examination of the faecal material following freezing and transport to the UK are shown in Table II. As shown initially, no coliforms were isolated although these are normally common in faecal material. Aerobic bacteria included Bacillus spp. (B. pumilus, B. subtilis, B. licheniformis and B. sphaericus), Aerococcus spp., Micrococcus spp. and Corynebacterium spp. Viable alpha haemolytic Streptococci were also found. Coliforms were not detected while Enterococci were cultured in low numbers from only one sample $\left[\sim 1 \times 10^{2}\right.$ colony forming units (cfu) $\mathrm{g}^{-1}$. Anaerobic bacteria cultured included Clostridium perfringens, which is a common marker strain indicative of faecal contamination. Ova, cysts and parasites were not seen in the faecal material. 
Table I. Culture techniques for identification of faecal microorganisms.

\begin{tabular}{|c|c|c|c|}
\hline Microorganism & Growth medium & $\begin{array}{l}\text { Culture conditions: } \\
\text { oxygen, duration, temperature }\end{array}$ & Enrichment and identification \\
\hline aerobic colony count ${ }^{1}$ & Columbia blood agar & aerobic, $44 \mathrm{~h}, 37^{\circ} \mathrm{C}$ & Direct plating \\
\hline Bacillus spp. ${ }^{1}$ & $\begin{array}{l}\text { Polymyxin egg yolk mannite } \\
\text { Bromothymol blue agar }\end{array}$ & aerobic, $44 \mathrm{~h}, 37^{\circ} \mathrm{C}$ & $\begin{array}{l}\text { Bacillus spp. and other aerobic Gram positive } \\
\text { bacteria were identified using BBL Crystal } \\
\text { Gram Positive Identification System (Becton } \\
\text { Dickenson Ltd, Oxford) }\end{array}$ \\
\hline anaerobic colony count ${ }^{1}$ & Fastidious anaerobic agar & anaerobic, $44 \mathrm{~h}, 37^{\circ} \mathrm{C}$ & Direct plating \\
\hline Clostridium spp. ${ }^{2}$ & Fastidious anaerobic agar with neomycin & anaerobic, $44 \mathrm{~h}, 37^{\circ} \mathrm{C}$ & Direct plating \\
\hline Clostridium perfringens ${ }^{2}$ & Perfringens TSC agar & anaerobic, $44 \mathrm{~h}, 37^{\circ} \mathrm{C}$ & $\begin{array}{l}\text { Clostridium perfringens confirmed using API } \\
\text { Rapid 32A Identification System (Biomerieux } \\
\text { Ltd, Hampshire, UK) }\end{array}$ \\
\hline $\begin{array}{l}\text { Enterococci }^{1} \\
\text { number technique (MPN) }\end{array}$ & Azide dextrose broth by most probable & aerobic, $44 \mathrm{~h}, 37^{\circ} \mathrm{C}$ & $\begin{array}{l}\text { Confirmation onto Kanamycin aesculin azide } \\
\text { agar, aerobic, } 22 \mathrm{~h}, 44^{\circ} \mathrm{C}\end{array}$ \\
\hline $\begin{array}{l}\text { coliform bacilli and } \\
\text { Escherichia coli (non-O157) }\end{array}$ & $\begin{array}{l}\text { Most probable number technique (MPN) } \\
\text { in minerals modified glutamate broth }\end{array}$ & aerobic, $44 \mathrm{~h}, 37^{\circ} \mathrm{C}$ & \\
\hline Salmonella spp., Shigella spp. ${ }^{2}$ & $\begin{array}{l}\text { Xylose lysine desoxycholate agar and } \\
\text { Hynes desoxycholate citrate agar }\end{array}$ & aerobic, $22 \mathrm{~h}, 37^{\circ} \mathrm{C}$ & $\begin{array}{l}\text { Enrichment for Salmonella spp. in single } \\
\text { strength selenite F broth, aerobic, } 37^{\circ} \mathrm{C}, 24 \mathrm{~h}\end{array}$ \\
\hline Campylobacter spp. ${ }^{3}$ & Cefoperazone charcoal desoxycholate agar & $\begin{array}{l}\text { micro-aerophilic, } \\
90 \mathrm{~h}, 42^{\circ} \mathrm{C}\end{array}$ & $\begin{array}{l}\text { Enrichment in Campylobacter broth, aerobic, } \\
37^{\circ} \mathrm{C}, 24 \mathrm{~h}\end{array}$ \\
\hline Escherichia coli $0157^{2}$ & Cefixime-tellurite sorbitol MacConkey agar & aerobic, $22 \mathrm{~h}, 37^{\circ} \mathrm{C}$ & Direct plating \\
\hline Vibrio spp. ${ }^{2}$ & Thiosulphate citrate bile sucrose agar & aerobic, $22 \mathrm{~h}, 37^{\circ} \mathrm{C}$ & Direct plating \\
\hline Staphylococcus aureus ${ }^{2}$ & Baird Parker agar & aerobic, $44 \mathrm{~h}, 37^{\circ} \mathrm{C}$ & Direct plating \\
\hline
\end{tabular}

${ }^{1}$ Roberts et al. $1995 \quad{ }^{2}$ Public Health Laboratory Services 1998a

${ }^{3}$ Public Health Laboratory Services 1998 b

\section{Discussion}

This study has shown that faecal Enterococci and sporeforming Bacillus and Clostridium species can survive in the climatic conditions of the Antarctica Peninsula for 30-40 years. Under both aerobic and anaerobic conditions, cultured bacteria were predominantly spore-forming species, i.e. Bacillus spp. or C. perfringens. Gram negative coliform bacteria were not cultured from the material, and have been shown previously to be particularly susceptible to damage by freeze-thaw stress (Parker \& Martel 2002). Our data are in agreement with work carried out by Meyer et al. (1963) who examined human faecal material produced in the first decade of the last century (50 years previously) by Scott and Shackleton's expeditions at McMurdo Sound, continental Antarctica. They cultured Clostridium spp. and Bacillus spp., but found no evidence of Escherichia coli or other coliform bacteria. Nedwell et al. (1994) quantified faecal bacteria in pony dung found at Scott's camps at Cape Evans dating from around the same period (1910-11). With aerobic culture on Casein Peptone Starch Agar they found

Table II. Counts of bacteria within Fossil Bluff dump faecal material

\begin{tabular}{|c|c|c|c|c|c|}
\hline \multirow[t]{2}{*}{ Microorganisms } & \multicolumn{5}{|c|}{ Sample Number } \\
\hline & 1 & 2 & 3 & 4 & 5 \\
\hline aerobic bacteria ( $\mathrm{cfu} \mathrm{g}^{-1}$ ) & $4.8 \times 10^{3}$ & $2.4 \times 10^{7}$ & $7.5 \times 10^{5}$ & $1.8 \times 10^{4}$ & $5.0 \times 10^{6}$ \\
\hline anaerobic bacteria $\left(\mathrm{cfu} \mathrm{g}^{-1}\right)$ & $6.0 \times 10^{6}$ & $2.2 \times 10^{5}$ & $3.2 \times 10^{5}$ & $6.0 \times 10^{4}$ & $6.0 \times 10^{5}$ \\
\hline Clostridium perfringens $\left(\mathrm{cfu} \mathrm{g}^{-1}\right)$ & $+\mathrm{a}$ & $1.7 \times 10^{5}$ & $1.2 \times 10^{2}$ & $2.5 \times 10^{4}$ & $5.0 \times 10^{1}$ \\
\hline Enterococci $\left(\mathrm{cfu} \mathrm{g}^{-1}\right)$ & $1.4 \times 10^{2}$ & nd & nd & nd & nd \\
\hline Coliform bacilli and Escherichia coli (non-0157) & nd & nd & nd & nd & nd \\
\hline Shigella spp. (cfu $\left.25 \mathrm{~g}^{-1}\right)$ & nd & nd & nd & nd & nd \\
\hline Campylobacter spp. (cfu $50 \mathrm{~g}^{-1}$ ) & nd & nd & nd & nd & nd \\
\hline Escherichia coli 0157 (cfu $25 \mathrm{~g}^{-1}$ ) & nd & nd & nd & nd & nd \\
\hline Vibrio spp. $\left(\mathrm{cfu} \mathrm{g}^{-1}\right)$ & nd & nd & nd & nd & nd \\
\hline Staphylococcus aureus $\left(\mathrm{cfu} \mathrm{g}^{-1}\right)$ & nd & nd & nd & nd & nd \\
\hline
\end{tabular}

nd: not detected $\quad{ }^{a}$ present in sample but not enumerated 
up to $1.9 \times 10^{6} \mathrm{cfu} \mathrm{g}^{-1}$ pony dung, which upon further examination were mainly Bacillus spp. Taking the data of Meyer et al. into consideration, Nedwell et al. concluded that coliforms can survive $<50$ years and sporing bacteria $>80$ years in a continuously frozen state in Antarctica. From our study, we can reduce the survival time of coliforms to $<30$ years and confirm the survival of sporing bacteria to be $>30$ years in the Antarctic Peninsula. Survival of aerobic bacteria in 30-40 year old human faecal material from Fossil Bluff ranged from $4.8 \times 10^{3}$ to $2.4 \times 10^{7} \mathrm{cfu} \mathrm{g}^{-1}$ [mean $=6.0 \times 10^{6}\left(\right.$ S.E. $\left.\left.\pm 4.6 \times 10^{6}\right)\right]$. The mean value is lower than found previously in older, though continuously frozen, faecal material from McMurdo $\left(2 \times 10^{7} \mathrm{cfu} \mathrm{g}^{-1} ; 50\right.$ years old) (Meyer et al. 1963). This difference may be a consequence of the greater number of fluctuations around freezing point experienced at Fossil Bluff compared to McMurdo Sound (Harangozo et al. 1997, S. Colwell, personal communication 2003), leading to increased freeze/thaw damage to cells (Sanin et al. 1994, Parker et al. 2000) (Fig. 2). The finding that the faecal material at Fossil Bluff was not frozen when initially collected from the dump may corroborate this.

Bacillus spp. were found in Antarctic faecal material examined by Meyer et al. (1963), Nedwell et al. (1994) and in this study. However, Bacillus spp. are common environmental isolates and despite careful sampling protocols, may have come from other sources.

With the application of molecular biological techniques it is now possible to detect DNA from human faecal microorganisms in supposedly pristine Antarctic soils. For example, Sjoling \& Cowan (2000) found residual levels of non-indigenous bacteria at abandoned Antarctic field camps using PCR amplification of extracted soil DNA, though Upton et al. (1997) failed to detect human commensals using PCR around Halley Bay Research Station. Baker et al. (2003) list a number of PCR primers for specific microbial species, which could be used in pristine environments to detect microorganisms indicative of human impact. Whilst a major methodological advance, this technique does not indicate whether the microorganisms are viable, for which we have to rely on traditional culture techniques for the foreseeable future.

\section{Impact of regional climate change}

Antarctic Treaty Parties face the legacy of waste dumped in the Antarctic terrestrial environment by earlier expeditions. Previous methods of human waste disposal on land are now starting to produce detectable but localized environmental pollution as well as potential health and scientific problems. In some areas of the Antarctic Peninsula, regional warming has caused a decrease in permanent snow cover around nunataks and coastal regions (Fox \& Cooper 1998) with the result that previously buried toilet pits, depots and food dumps are now melting out. At Sky Hi Nunataks
(P. Convey, personal communication 2003) and Witte Nunataks (southern Antarctic Peninsula; M. Hunter, personal communication 2003), faecal material was encountered in 2001 by BAS field parties that may have been derived from either dogs or humans in travelling geological field parties dating back to the 1970s. Also, buried faecal material on glacier surfaces are now being rediscovered due to reduced annual snow accumulation, and increased surface melt and ablation. For example, the surface lowering of the ice ramp at Rothera Point, which Smith et al. (1999) attributed to regional climate change, has resulted in dog faeces (dating from before February 1994) coming to the surface through ice melt (Hughes, personal observation 2001). As well having health and safety implications, buried faecal material can cause other practical problems: in January 2001 a BAS Twin Otter aircraft, upon landing at Utopia Glacier, Alexander Island, caught one of its skis in an unmarked old toilet pit that had become partially exposed (Hughes, personal observation 2001).

\section{Science implications}

Scientists must select carefully their study sites to avoid areas of previous human impact. Unfortunately, these sites are often only poorly mapped, especially in remote field locations and on the polar plateau. In the early 1970s, BAS glaciologists working on the George VI Ice Shelf drilled an ice core through some dog faeces left by an earlier expedition (D. Peel, personal communication 2003). At sites of unique scientific importance, the cumulative impact of scientists working in the same place for many seasons can have significant consequences. For example, ten persons working for three summer seasons would produce over $1000 \mathrm{~kg}$ of faecal waste. Under Annex III (waste disposal and waste management) of the Environmental Protocol the Treaty nations are required to "prepare an inventory of locations of past activities (such as traverses, fuel depots, field bases, crashed aircraft) as far as is practicable, before the information is lost, so that such locations can be taken into account in planning future scientific programmes (such as snow chemistry, pollutants in lichens, ice core drilling)'. However, even if adequately carried out today, this does not provide information on the burial of faecal waste over the past 100 years.

\section{Conclusions}

This study has shown that faecal Enterococci and sporeforming aerobes and anaerobes present in 30-40 year old human faeces have survived the climatic conditions of the Antarctic Peninsula, including repeated freeze-thaw cycles. Increased rates of snow and ice melt, possibly associated with regional climate change, have resulted in previously buried faecal material becoming exposed. Effective 
implementation of the requirements of the Environmental Protocol is therefore needed, as well as research and development of alternative methods of human waste disposal in inland areas of Antarctica.

Annex III of the Protocol on Environmental Protection to the Antarctic Treaty (1991) requires that existing Antarctic waste disposal sites are cleaned up. In the summer of 2002-03, BAS completely removed the waste dump at Fossil Bluff (approximately 52 tonnes of waste) by Twin Otter aircraft to Rothera Research Station, after which it was transported by sea for recycling or safe disposal either in the Falkland Islands or the United Kingdom (Plato 2001). The results from this study were used to implement correct and safe working practices for the removal of the faecal material from the dump site: personnel were provided with disposable safety clothing and washing facilities, and all material associated with faecal material was treated as biohazard waste.

\section{Acknowledgements}

This work was supported by the British Antarctic Survey's 'Biomolecular Responses to Environmental Stresses in the Antarctic' project and the Environment and Information Division.

We thank Nigel Blenkharn for help with sample collection, Steve Colwell for meteorological data and Pete Marquis for logistical assistance. M. Hunter, D. Peel and R. Mulvaney are thanked for historical information. P. Fretwell is acknowledged for map preparation and Drs P. Convey and J. Shears for comments on the manuscript. We thank the referees, D. Cowan, D. Nedwell and L. Parker, for their constructive help.

\section{References}

ANON. 1994. The microbiology of water 1994. Part 1 - drinking water. Methods for the examination of waters and associated materials. Report on public health and medical subjects no. 71. London: HMSO.

Antarctic Treaty Consultative Parties. 1991. Protocol on Environmental Protection to the Antarctic Treaty. CM 1960. London: HMSO, 38 pp.

BAKER, G.C., Tow, L.A. \& CowAN, D.A. 2003. PCR-based detection of non-indigenous microorganisms in 'pristine' environments. Journal of Microbiological Methods, 53, 157-164.
Fox, A.J. \& COOPER, A.P.R. 1998. Climate-change indicators from archival aerial photography of the Antarctic Peninsula. Annals of Glaciology, 27, 636-642.

Harangozo, S.A., Colwell, S.R. \& King, J.C. 1997. An analysis of a 34year air temperature record from Fossil Bluff $\left(71^{\circ} \mathrm{S}, 68^{\circ} \mathrm{W}\right)$, Antarctica. Antarctic Science, 9, 355-363.

HugHES, K.A. 2003. Influence of seasonal environmental variables on the distribution of presumptive fecal coliforms around an Antarctic research station. Applied and Environmental Microbiology, 69, 4884-4891.

Hughes, K.A. \& Blenkharn, N. 2003. A simple method to reduce discharge of sewage microorganisms from an Antarctic research station. Marine Pollution Bulletin, 46, 353-357.

McFeters, G.A., BarRy, J.P. \& Howington, J.P. 1993. Distribution of enteric bacteria in Antarctic seawater surrounding a sewage outfall. Water Research, 27, 645-650.

Meyer, G.H., Morrow, M.B. \& Wyss, O. 1963. Viable organisms from faeces and foodstuffs from early Antarctic expeditions. Canadian Journal of Microbiology, 9, 163-167.

Nedwell, D.B., Russell, N.J. \& Cresswell-Maynard, T. 1994. longterm survival of microorganisms in frozen material from early Antarctic base camps at McMurdo Sound. Antarctic Science, 6, 67-68.

Parker, L.V., Yushak, M.L., Martel, C.J. \& Reynolds, C.M. 2000. Bacterial survival in snow made from wastewater. Hanover: US Army Engineer Research and Development Centre, Cold Regions Research and Engineering Laboratory, ERDC/CRREL Report TR-00-9, 22 pp.

PARKER, L.V. \& MARTEL, C.J. 2002. Long-term survival of enteric microoganisms in frozen wastewater. Hanover: US Army Engineer Research and Development Centre, Cold Regions Research and Engineering Laboratory, ERDC/CRREL Report TR-02-16, 64 pp.

Plato, N. 2001. Fossil Bluff waste dump and asbestos survey. British Antarctic Survey unpublished report.

Public Health Laboratory Service. 1998a. PHLS standard operating procedure. Investigation of faecal specimens for bacterial pathogens. London: PHLS B.SOP 30.

Public Health Laboratory Service. 1998b. PHLS standard methods for food products. Detection of Campylobacter spp. London: PHLS F21.

Public Health Laboratory Service. 1998c. PHLS standard operating procedure. Investigation of specimens other than blood for parasites. London: PHLS B.SOP 31.

Roberts, D., Hooper, W., \& Greenwood, M. 1995. Practical food microbiology. London: Public Health Laboratory Service, London, $240 \mathrm{pp}$.

Sanin, F.D., Vesilind, P.A. \& Martel, C.J. 1994. Pathogen reduction capabilities of freeze/thaw sludge conditioning. Water Research, 28, 2393-2398.

SJoling, S. \& Cowan, D.A. 2000. Detecting human bacterial contamination in Antarctic soils. Polar Biology, 23, 644-650.

Smith, A.M., Vaughan, D.G., Doake, C.S.M. \& Johnson, A.C. 1999. Surface lowering of the ice ramp at Rothera Point, Antarctic Peninsula, in response to regional climate change. Annals of Glaciology, 27, $113-118$.

Upton, M., Pennington, T.H. \& Haston, W. 1997. Detecting commensals in the area around an Antarctic research station. Antarctic Science, 9, 156-161. 